\title{
An AHP Model towards an Agile Enterprise
}

\author{
Mohamed Amine Marhraoui* \\ TIME laboratory, ENSIAS Engineering School, Mohammed \\ V University in Rabat, Morocco
}

\author{
Abdellah El Manouar \\ TIME laboratory, ENSIAS Engineering School, Mohammed \\ V University in Rabat, Morocco
}

\begin{abstract}
Companies are facing different challenges in order to adapt to their environmental context. They should be aware of the changes on the social, political, ecological and economical levels. Moreover, they should act in an efficient and rapid manner by leveraging new and reconfigurable resources. Organizational agility is the firm's key dynamic capability which enables it to deal with changes and exploit them as opportunities. Firms' objective is thus to attain a higher degree of agility which can help them to perform durably. In this article, a new model based on analytical hierarchy process (AHP) method is proposed. This can help companies to raise their agility level by deploying the most suitable agility enablers which can be either general or specific when related to information technologies. They can thus develop the most appropriate strategy towards agility regarding their internal and external contexts.
\end{abstract}

Keywords-Organizational agility; analytical hierarchy process; information technology; agility enablers

\section{INTRODUCTION}

The international context of companies is characterized by increased competition due to globalization, free trade and low cost labor in Asian and other emerging countries.

In addition, the local environment for companies is rapidly changing as countries are adopting new laws regularly, adapting their monetary/fiscal policies and facing social challenges.

Companies should in this rapidly changing environment, adapt their strategies regularly in order to manage risks and to create a competitive advantage.

They should thus be agile regarding their current and future environmental challenges.

Organizational agility is the firm's dynamic capability which allows it to combine the features of chaos and flexibility with a minimum of order, control, and predictability [1], [2].

It is the ability of the firm to sense changes in its environment and to respond in an adequate and rapid manner [3], [4].

The aim of companies is to enhance their agility's level continuously. They should be able to detect key levers and develop thus a strategy towards agility.

In this paper, a new model based on multi criteria method (AHP) is proposed. It allows the company to define a global strategy by leveraging agility's enablers based on their weights. Then, the IT levers of agility are highlighted. The company can activate them and integrate them into its IT strategy in order to be more agile. The presented model is original as previous works have proposed methods in order to assess firm's agility without proposing a detailed strategy for improvement [5].

The structure of this work is organized as follow. Section II is dedicated to the definition of AHP method, its advantages and main applications. In Section III, the organizational agility concept is defined. Then, the adopted methodology and the AHP model are described. Section IV allows illustrating the application of the proposed model. It presents the global and IT specific methods for enhancing enterprise agility. Finally, Section $\mathrm{V}$ provides a brief conclusion of this article and the future research perspectives.

\section{AHP}

\section{A. Definition}

AHP is a multi-criteria approach for decision making based on the definition of a goal as a top priority and on a decision hierarchy from the highest to the lowest criteria in term of importance [6].

AHP starts from the judgments of decision makers to form a decomposition of problems into hierarchies. The problem complexity is represented by the number of levels in the hierarchy which combine with the decision maker's model of the problem to be solved.

Decision making process through AHP requires two phases: design and evaluation.

Design, as described earlier, is reaching a consensus about the hierarchy model.

Evaluation is based on pair wise comparison. The criterions on the same level of the hierarchy are compared with each others, and with other elements on the level above [7].

The pair wise comparison is accomplished thanks to the use of a square matrix. As in (1), the rows and columns represent the criterions which are compared and the entries of each cell of the matrix represent the weight of an element of the matrix when compared to another element.

$$
\mathrm{A}=\left[\begin{array}{ccc}
a 11 & \cdots & a 1 n \\
\vdots & \ddots & \vdots \\
a n 1 & \cdots & \text { ann }
\end{array}\right]=\left[\begin{array}{ccc}
1 & \cdots & w 1 / w n \\
\vdots & \ddots & \vdots \\
w n / w 1 & \cdots & 1
\end{array}\right]
$$

Where, $a i j=w i / w j$ and aij represents the importance of the weight wi over wj.

The matrix A has positive entries everywhere and satisfies the reciprocal property aji $=1 / a \mathrm{aj}$. This kind of matrix with this property is called a reciprocal matrix. 
Saaty, 1977 proposed a hierarchical decomposition in which the elements are grouped in classes of about 7 elements each, in order to limit the number of comparisons required and to minimize the number of errors that could arise. Thus, a 1-9 scale is used in order to assign weights to each criterion (Table 1). In the case of this article, a linear scale is used [8][10].

There are other scales for comparisons in the literature [10]- [17] (Table 2).

TABLE I. THE LINEAR SCALE FOR COMPARISONS (SAATY, 1977) [10]

\begin{tabular}{|l|l|}
\hline Intensity of importance & Description \\
\hline 1 & Equal Importance \\
\hline 3 & Moderate importance \\
\hline 5 & Strong importance \\
\hline 7 & Very strong importance \\
\hline 9 & Extreme importance \\
\hline $2,4,6,8$ & Intermediate values \\
\hline Reciprocals & Values for inverse comparison \\
\hline
\end{tabular}

TABLE II. THE DIFFERENT SCALES FOR COMPARISONS (ISHIZAKA \& LABIB, 2009) [10]

\begin{tabular}{|c|c|c|c|c|c|c|c|c|c|}
\hline \multirow{2}{*}{$\begin{array}{l}\text { Scale Type } \\
\text { Linear } \\
\text { (Saaty 1977) } \\
{[10]}\end{array}$} & \multicolumn{9}{|c|}{ Values } \\
\hline & 1 & 2 & 3 & 4 & 5 & 6 & 7 & 8 & 9 \\
\hline 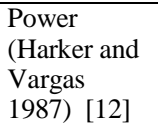 & 1 & 4 & 9 & 16 & 25 & 36 & 49 & 64 & 81 \\
\hline $\begin{array}{l}\text { Geometric } \\
\text { (Lootsma } \\
\text { 1989) [13] }\end{array}$ & 1 & 2 & 4 & 8 & 16 & 32 & 64 & 128 & 256 \\
\hline $\begin{array}{l}\text { Logarithmic } \\
\text { (Ishizaka, } \\
\text { Balkenborg } \\
\text { et al. 2006) } \\
\text { [14] }\end{array}$ & 1 & $\begin{array}{l}1.5 \\
8\end{array}$ & 2 & $\begin{array}{l}2.3 \\
2\end{array}$ & $\begin{array}{l}2.5 \\
8\end{array}$ & $\begin{array}{l}2.8 \\
1\end{array}$ & 3 & $\begin{array}{l}3.1 \\
7\end{array}$ & $\begin{array}{l}3.3 \\
2\end{array}$ \\
\hline $\begin{array}{l}\text { Root square } \\
\text { (Harker and } \\
\text { Vargas } \\
1987 \text { [12] }\end{array}$ & 1 & $\begin{array}{l}1.4 \\
1\end{array}$ & $\begin{array}{l}1.7 \\
3\end{array}$ & 2 & $\begin{array}{l}2.2 \\
3\end{array}$ & $\begin{array}{l}2.4 \\
5\end{array}$ & $\begin{array}{l}2.6 \\
5\end{array}$ & $\begin{array}{l}2.8 \\
3\end{array}$ & 3 \\
\hline $\begin{array}{l}\text { Asymptotica } \\
1 \text { (Dodd and } \\
\text { Donegan } \\
1995)[15]\end{array}$ & 0 & $\begin{array}{l}0.1 \\
2\end{array}$ & $\begin{array}{l}0.2 \\
4\end{array}$ & $\begin{array}{l}0.3 \\
6\end{array}$ & $\begin{array}{l}0.4 \\
6\end{array}$ & $\begin{array}{l}0.5 \\
5\end{array}$ & $\begin{array}{l}0.6 \\
3\end{array}$ & $\begin{array}{l}0.7 \\
0\end{array}$ & $\begin{array}{l}0.7 \\
6\end{array}$ \\
\hline $\begin{array}{l}\text { Inverse } \\
\text { linear ( Ma } \\
\text { and Zheng } \\
1991) \text { [16] }\end{array}$ & 1 & $\begin{array}{l}1.1 \\
3\end{array}$ & $\begin{array}{l}1.2 \\
9\end{array}$ & 1.5 & 1.8 & $\begin{array}{l}2.2 \\
5\end{array}$ & 3 & 4.5 & 9 \\
\hline $\begin{array}{l}\text { Balanced } \\
\text { (Salo and } \\
\text { Hamalainen } \\
\text { 1997) [17] }\end{array}$ & 1 & $\begin{array}{l}1.2 \\
2\end{array}$ & 1.5 & $\begin{array}{l}1.8 \\
6\end{array}$ & $\begin{array}{l}2.3 \\
3\end{array}$ & 3 & 4 & $\begin{array}{l}5.6 \\
7\end{array}$ & 9 \\
\hline
\end{tabular}

The Eigenvalue method is used in order to derive priorities among criterions/sub-criterions. Thus, priorities' vector is the principal eigenvector of the matrix. It is a vector $\omega$ of order $n$ such that $A \omega=\lambda \omega$. For such a matrix, $\omega$ is said to be an eigenvector and $\lambda$ is an eigenvalue [18].

The largest eigenvalue $\lambda \max$ of the comparison matrix is used to calculate the consistency index. The difference between $\lambda \max$ and $\mathrm{n}$ is an indication of the inconsistency of the judgments. The consistency index (CI) can be calculated using (2) [19].

$$
\mathrm{CI}=(\lambda \max -\mathrm{n}) /(\mathrm{n}-1)
$$

Then, the consistency ratio (CR) is calculated by dividing the consistency index (CI) and the random index (RI) (3).

$$
\mathrm{CR}=\frac{\mathrm{CI}}{\mathrm{RI}}
$$

Saaty, 1980 describes average RI values of randomly generated matrices of different sizes.

Moreover, he suggests that if the consistency ratio (CR) exceeds 0.1 , the set of judgments may be too inconsistent to be reliable. In practice, CRs of more than 0.1 have to be sometimes accepted [20].

Finally, the global priority is obtained by multiplying the priorities values of the criterions/sub-criterions across the hierarchy.

\section{B. Advantages and Applications}

AHP is an intuitive and flexible method. It allows, in addition, checking the inconsistencies in judgments [21].

It has applications in several domains. For example, in operations management, AHP can be used for "make or buy" decisions, project risk analysis [22], supplier selection [23] and strategic solutions for alternate energy/emissions management [24].

In addition, AHP can be used in software selection based on technical and managerial considerations [25].

Wei et al., 2005 proposed an AHP-based approach to select the most suitable ERP system which allows the company to enhance its performance and competitiveness [26].

Other applications proposed by Melvin, 2012 are related to choosing among different strategies for improving safety features in motor vehicles or for evaluating the quality of research and investment proposals [27].

\section{PROPOSITION OF AN AHP MODEL FOR AN AGILE ENTERPRISE}

\section{A. Organizational Agility}

The history of agility began in the USA in order to help the American industry to regain the leading position which was lost during the 70s and 80s in favor of Japanese and European industries.

Organizational agility is the capacity of a company to adapt itself to the changes in its environment and to exploit it as opportunities of development and growth through fast and innovative responses [28]. 
Organizational agility enables firms, by sensing changes in the environment, to prioritize and choose the best solution among the possible alternatives, to reconfigure business processes and to customize real-time response [29].

There are two main distinct components of agility: 1) sensing; and 2) responding.

Sensing is related to scanning the environment through exploring and incorporating new knowledge [30].

The second component refers to responding to changing market conditions in a reactive or proactive manner [31].

These sensing and responding components should be aligned in order to maximize the impact of agility on firm's performance [32].

\section{B. The Methodology}

Fig. 1 below describes the methodology adopted for this study. First, the AHP hierarchy is defined by setting the goal, the criterions and sub-criterions.

Then, based on pair wise comparisons, the weights of each criterion and sub-criterion are calculated.

Finally, a threshold is fixed which and allows selecting the general agility's levers and the specific IT levers of agility.

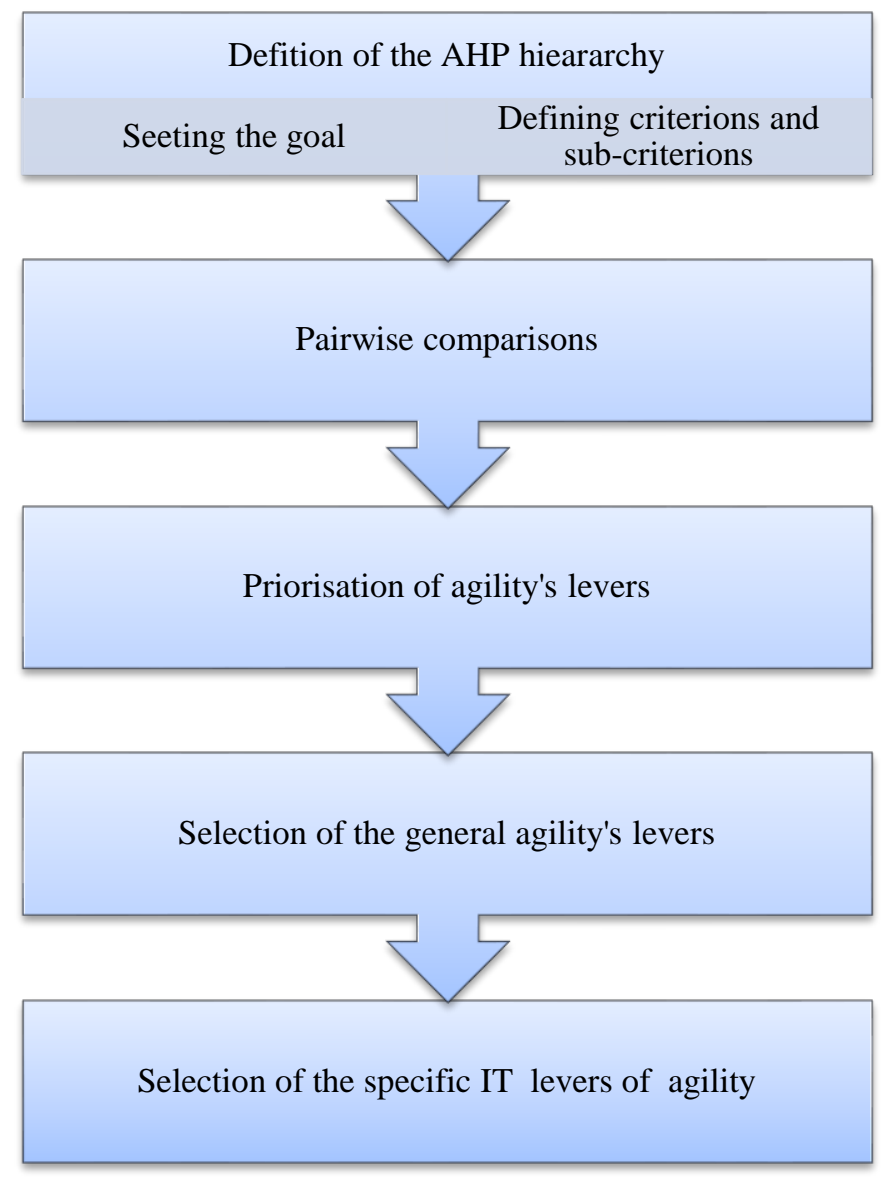

Fig. 1. The adopted methodology.

\section{AHP Model proposition}

The proposed model has three levels (Table 3):

- The goal is to achieve the firm's agility.

- The criterions and sub-criterions include the main agility enablers. They belong to six groups: IT, human resources, process, knowledge management, organizational structure and innovation [33].

TABLE III. THE PROPOSED HIERARCHY

\begin{tabular}{|c|c|c|}
\hline $\begin{array}{l}\text { Level (0) } \\
\text { Goal }\end{array}$ & $\begin{array}{l}\text { Level (1) } \\
\text { Criterion }\end{array}$ & $\begin{array}{l}\text { Level (2) } \\
\text { Sub-criterion }\end{array}$ \\
\hline \multirow{21}{*}{$\begin{array}{l}\text { Agile } \\
\text { enterprise }\end{array}$} & \multirow{5}{*}{ IT } & IT resources \\
\hline & & IT skills \\
\hline & & IT acceptance \\
\hline & & IT innovation \\
\hline & & Knowledge management systems \\
\hline & \multirow{6}{*}{ Human resources } & Mindset \\
\hline & & Behavior \\
\hline & & Planning \\
\hline & & Training \\
\hline & & Evaluation \\
\hline & & Motivation \\
\hline & \multirow{2}{*}{ Process } & Flexible process \\
\hline & & Efficient decision making \\
\hline & \multirow{3}{*}{$\begin{array}{l}\text { Knowledge } \\
\text { management }\end{array}$} & Capitalizing knowledge \\
\hline & & $\begin{array}{l}\text { Balance in managing knowledge and } \\
\text { change }\end{array}$ \\
\hline & & Learning organization \\
\hline & \multirow{3}{*}{$\begin{array}{l}\text { Organizational } \\
\text { structure }\end{array}$} & Adaptable structure \\
\hline & & $\begin{array}{l}\text { Independent/multidisciplinary } \\
\text { business units }\end{array}$ \\
\hline & & Self-organization \\
\hline & \multirow{2}{*}{ Innovation } & Introduction of new products \\
\hline & & Entering new markets \\
\hline
\end{tabular}

\section{Illustration : Practical ApPlication of the MODEL FOR THE DEFINITION OF A GLOBAL AND IT STRATEGY TOWARDS AGILITY}

The purpose of the proposed model is to allow companies to prioritize the most relevant attributes enabling them to be more agile.

The global approach is based on the by classification of the sub-criterions related to six enablers groups: IT, HR, process, knowledge management, organizational structure and innovation. Then, a specific approach related to IT is proposed.

The data is used below for illustration purposes of the proposed model.

The PriEST software, which is an open-source priority estimation tool developed by Sajid Siraj is adopted [34]. 


\section{A. Pairwise Comparisons}

First, a first pair wise comparison of the six criterions of level (1) is made.

Fig. 2 below presents a graph view of this pair wise comparison using the PriEsT tool $(\mathrm{CR}=2,5 \%<0,1)$.

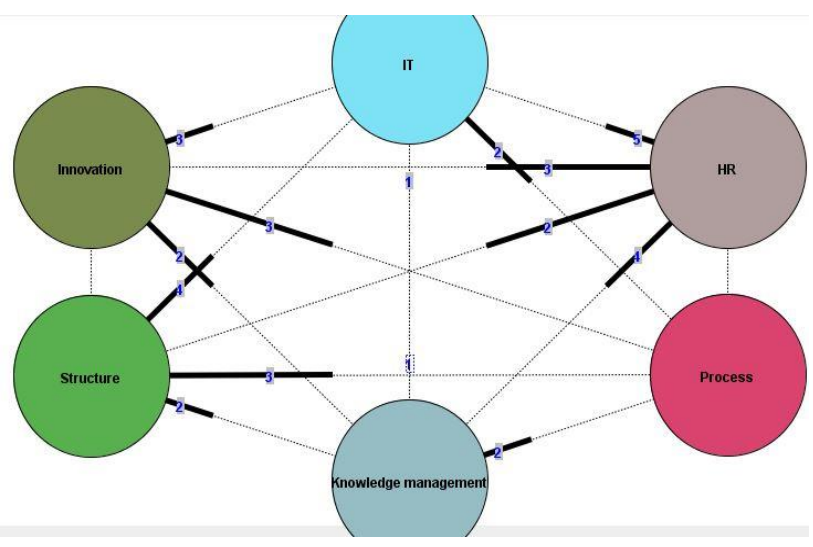

Fig. 2. Graph view of pair wise comparison between the six criterions.

\section{B. Prioritization of Agility's Levers}

Then, a pair wise comparison between sub-criterions of level (2) is performed $(\mathrm{CR}=7,7 \%<0,1)$.

This allows calculating the priorities (column on the right) among agility's levers using the BPMSG AHP Online System which apply the eigenvector method [35] (Fig. 3).

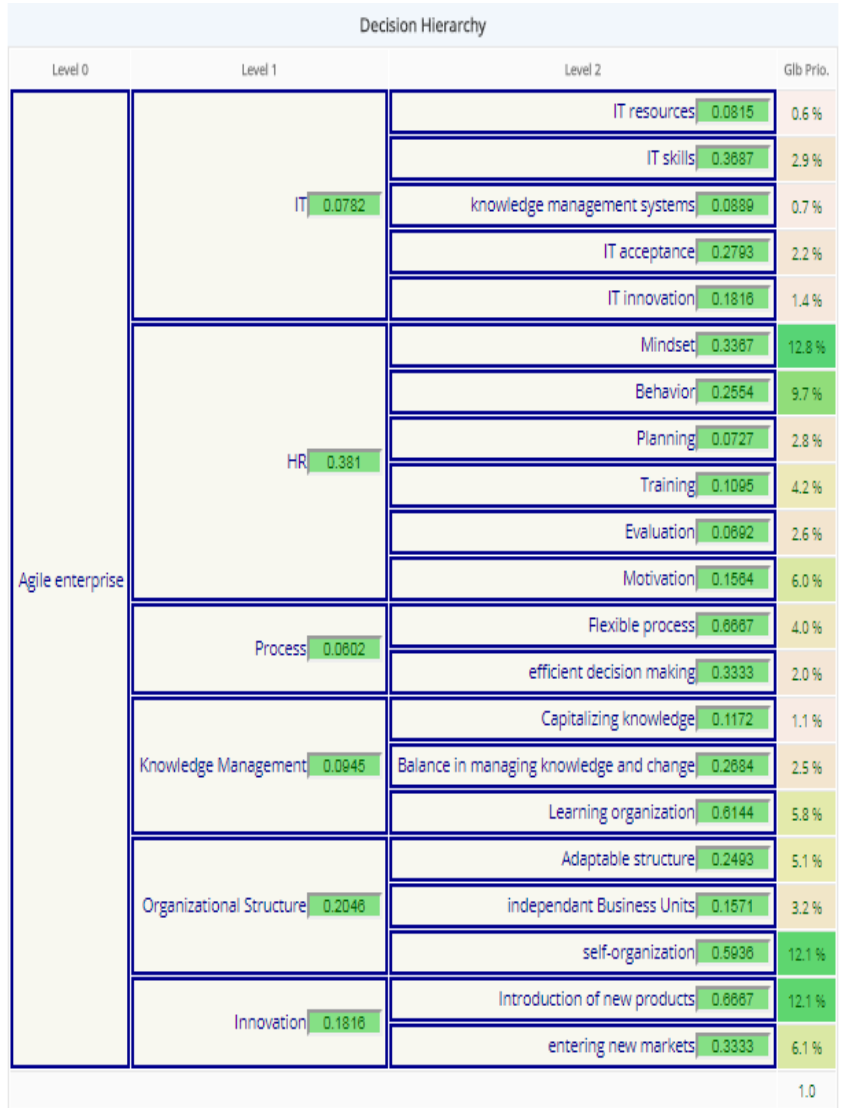

Fig. 3. Prioritization of agility's levers.

\section{Global Approach towards Agility}

In order to select the most influencing levers on which the company should focus, a threshold is calculated as (4):

Threshold $=1 / N B$ (agility's levers)

As presented in Table 4 below, the agility's levers with a priority which is higher or equal to the previous threshold are selected.

In this example, Threshold $=1 / 19=0,047619$.

TABLE IV. SELECTION OF THE MOST INFLUENCING AGILITY ENABLERS

\begin{tabular}{|l|l|l|}
\hline Agility's enablers & Priority & $\begin{array}{l}\text { Selected } \\
\text { agility's } \\
\text { enabler }\end{array}$ \\
\hline IT resources & 0,006368 & No \\
\hline IT skills & 0,028816 & No \\
\hline knowledge management systems & 0,006946 & No \\
\hline IT acceptance & 0,021835 & No \\
\hline IT innovation & 0,014198 & No \\
\hline Mindset & $\mathbf{0 , 1 2 8 2 7 5}$ & Yes \\
\hline Behavior & $\mathbf{0 , 0 9 7 3 1 2}$ & Yes \\
\hline Planning & 0,027706 & No \\
\hline Training & 0,041726 & No \\
\hline Evaluation & 0,026379 & No \\
\hline Motivation & 0,059589 & Yes \\
\hline Flexible process & 0,040139 & No \\
\hline efficient decision making & 0,020069 & No \\
\hline Capitalizing knowledge & 0,011075 & No \\
\hline Balance in managing knowledge and change & 0,025359 & No \\
\hline Learning organization & $\mathbf{0 , 0 5 8 0 5}$ & Yes \\
\hline Adaptable structure & $\mathbf{0 , 0 5 1 0 0 8}$ & Yes \\
\hline Independent Business Units & 0,032131 & No \\
\hline self-organization & $\mathbf{0 , 1 2 1 4 5 1}$ & Yes \\
\hline Introduction of new products & $\mathbf{0 , 1 2 1 0 4 5}$ & Yes \\
\hline entering new markets & $\mathbf{0 , 0 6 0 5 2 2}$ & Yes \\
\hline & & \\
\hline
\end{tabular}

In conclusion, in order to enhance its agility, the focus should be in this example on employee's mindset, their behavior, their motivation, on having an adaptable/ learning and self-organized structure, and on innovation (introduction of new products, entering new markets).

\section{The IT Specific Approach towards Agility}

In the rest of this article, the agility's levers related to information technology (IT) are highlighted.

A third level is then added to the AHP model (Table 5 below). 
TABLE V. THE EXTENDED HIERARCHY RELATED TO IT LEVERS OF AGILITY

\begin{tabular}{|c|c|c|c|}
\hline $\begin{array}{l}\text { Level (0) } \\
\text { Goal }\end{array}$ & $\begin{array}{l}\text { Level (1) } \\
\text { Criterion }\end{array}$ & $\begin{array}{l}\text { Level (2) } \\
\text { Sub-criterion }\end{array}$ & $\begin{array}{l}\text { Level (3) } \\
\text { Sub-criterion }\end{array}$ \\
\hline \multirow{19}{*}{$\begin{array}{l}\text { Agile } \\
\text { enterprise }\end{array}$} & \multirow{19}{*}{ IT } & \multirow{3}{*}{ IT resources } & IT architecture(SOA) \\
\hline & & & Cloud computing \\
\hline & & & Interoperability \\
\hline & & \multirow{2}{*}{ IT skills } & Mastering IT resources \\
\hline & & & Use of HRIS \\
\hline & & \multirow{2}{*}{ IT acceptance } & Perceived ease of use of IT \\
\hline & & & Usefulness of IT \\
\hline & & \multirow{5}{*}{ IT innovation } & 3D printing \\
\hline & & & Robotics \\
\hline & & & RFID \\
\hline & & & IoT \\
\hline & & & Mobile \\
\hline & & \multirow{7}{*}{$\begin{array}{l}\text { Knowledge } \\
\text { management } \\
\text { systems }\end{array}$} & $\begin{array}{l}\text { Use of groupware and } \\
\text { workflow Tools }\end{array}$ \\
\hline & & & Use of Intranet/extranet \\
\hline & & & Use of DMS \\
\hline & & & Use of CMS \\
\hline & & & Decision support systems \\
\hline & & & Big data analytics \\
\hline & & & $\begin{array}{l}\text { Manage knowledge using } \\
\text { AI }\end{array}$ \\
\hline
\end{tabular}

Then, a pair wise comparison allows prioritizing the IT levers of agility based on their weights (the column on the right in Fig. 4 below) $(\mathrm{CR}=6,6 \%<0,1)$.

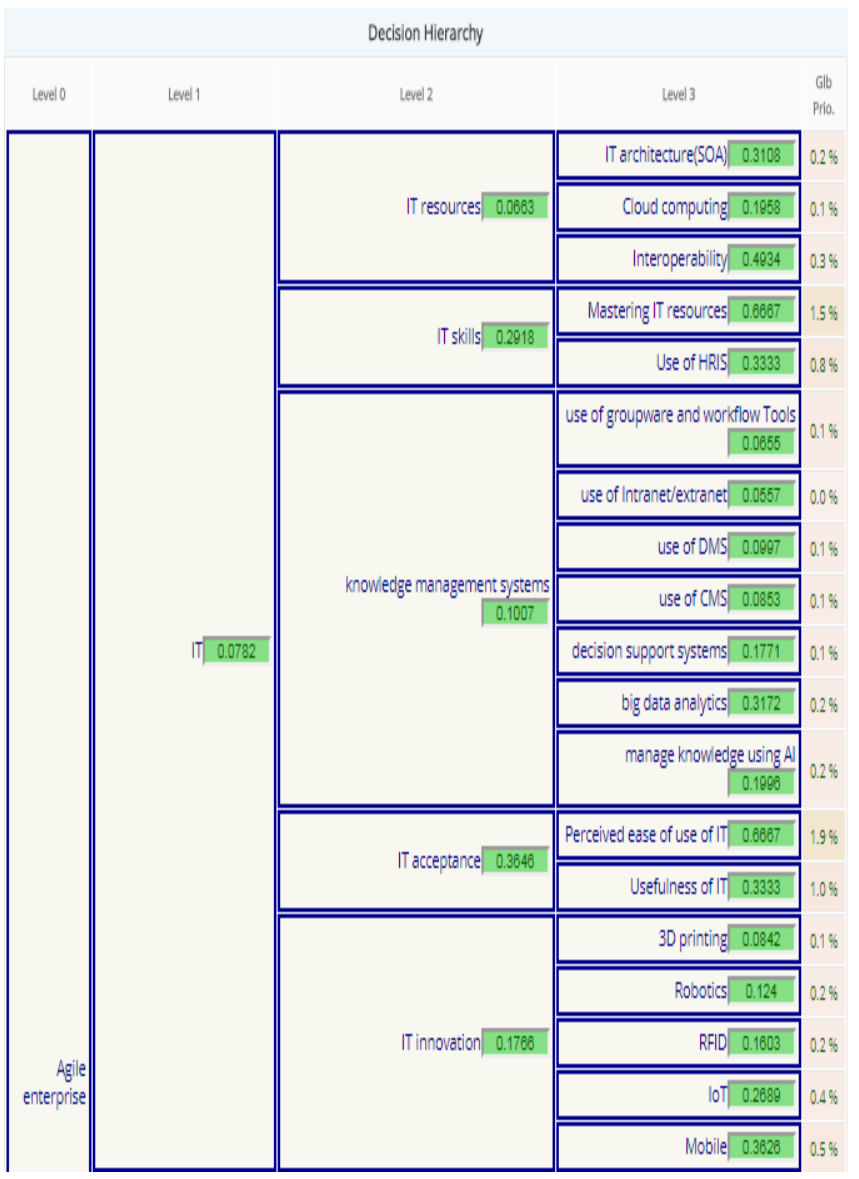

Fig. 4. Prioritization of IT levers of agility.
An IT threshold is calculated as the mean of the IT agility levers priorities (5).

In this example,

IT Threshold $=\sum$ IT levers of agility priorities $/ 19$

IT Threshold $=0,004113$

Then, the most influencing IT levers of agility are selected (Table 6 below).

TABLE VI. SELECTION OF THE MOST INFLUENCING IT LEVERS OF AGILITY

\begin{tabular}{|c|c|c|}
\hline IT levers of agility & Priority & $\begin{array}{r}\text { Selected IT } \\
\text { levers of agility }\end{array}$ \\
\hline IT architecture(SOA) & 0,00161 & No \\
\hline Cloud computing & 0,001014 & No \\
\hline Interoperability & 0,002556 & No \\
\hline Mastering IT resources & 0,015204 & Yes \\
\hline Use of HRIS & 0,007602 & Yes \\
\hline $\begin{array}{l}\text { use of groupware and workflow } \\
\text { Tools }\end{array}$ & 0,000515 & No \\
\hline use of Intranet/extranet & 0,000438 & No \\
\hline use of DMS & 0,000785 & No \\
\hline use of CMS & 0,000671 & No \\
\hline decision support systems & 0,001394 & No \\
\hline Big data analytics & 0,002496 & No \\
\hline Manage knowledge using AI & 0,001571 & No \\
\hline Perceived ease of use of IT & 0,019001 & Yes \\
\hline Usefulness of IT & 0,0095 & Yes \\
\hline $3 \mathrm{D}$ printing & 0,001162 & No \\
\hline Robotics & 0,001712 & No \\
\hline RFID & 0,002213 & No \\
\hline IoT & 0,003712 & No \\
\hline Mobile & 0,005006 & Yes \\
\hline
\end{tabular}

In this example, company should focus on using mobile, on IT acceptance (Usefulness and perceived ease of use of IT), and developing IT skills (mastering IT resources and using HRIS) among employees.

\section{CONCLUSION AND Future PERSPECTIVES}

The current article has allowed the proposition of a new model based on the AHP method. It may help companies to enhance their agility's level by selecting the most appropriate enablers regarding their context.

It can be improved and adapted to the company's internal and external environment. Thus, criterions and sub-criterions may be added or removed according to the company's resources or activity sector. 
Future research will focus on the application of the model in a real case through an action research methodology aggregating the pair wise comparisons across company's experts by using an appropriate survey.

\section{REFERENCES}

[1] Dyer, L., and Shafer, R., 2003, "Dynamic Organizations: Achieving Marketplace and Organizational Agility with People," (CAHRS Working Paper 03-04). Ithaca, NY: Cornell University, School of Industrial and Labor Relations, Center for Advanced Human Resource Studies.

[2] Wouter, A., De Smet, A. and Weerda, K., 2015, "Agility: It Rhymes with Stability," McKinsey Quarterly.

[3] Overby, E., Bharadwaj, A. and Sambamurthy, V. , 2006, "Enterprise agility and the enabling role of information technology," European Journal of Information Systems, 15(2), pp. 120-131.

[4] Lee, O., Sambamurthy, V., Lim, K.. and Wei, K., 2008, "IT-Enabled Organizational Agility and Sustainable Competitive Advantage," ICIS 2007 Proceedings. Paper 91.

[5] Marhraoui, M.A., El Manouar, A., 2017. "IT innovation and firm's sustainable performance: The mediating role of organizational agility," In the 9th International Conference on Information Management and Engineering (ICIME 2017).

[6] Saaty, T. L. 2008, "Decision making with the analytic hierarchy process," International journal of services sciences, 1(1), pp. 83-98.

[7] Vargas, L. G., 1990, "An overview of the analytic hierarchy process and its applications," European journal of operational research, 48(1), pp. 28.

[8] Akarte,M. M., Surendra, N. V., Ravi, B. \& Rangaraj, N., 2001, "Web based casting supplier evaluation using analytical hierarchy process," Journal of the Operational Research Society, pp. 511-522.

[9] Ishizaka ,A., and Labib,A., 2011, "Review of the main developments in the analytic hierarchy process," Expert systems with Applications, 38(11), pp. $14336-14345$.

[10] Saaty, T. L., 1977, "A scaling method for priorities in hierarchical structures," Journal of mathematical psychology, 15(3), pp. 234-281.

[11] Ishizaka, A., \& Labib, A. ,2009, "Analytic hierarchy process and expert choice: Benefits and limitations" Or Insight, 22(4), pp. 201-220.

[12] Harker, P. T., Vargas, L. G. ,1987, "The theory of ratio scale estimation: Saaty's analytic hierarchy process," Manage Sci 33, pp. 1383-1403.

[13] Lootsma, F. A., 1989, "Conflict resolution via pairwise comparison of concessions," European Journal of Operational Research, 40(1), pp. 109116.

[14] Ishizaka, A., Balkenborg, D., \& Kaplan, T., 2006,"Influence of aggregation and preference scale on ranking a compromise alternative in AHP," In Multidisciplinary Workshop on Advances in Preference Handling.

[15] Dodd, F. and H. Donegan, 1995, "Comparison of priotization techniques using interhierarchy mappings," Journal of the Operational Research Society, 46(4), pp. 492- 498.

[16] Ma, D. and Zheng, X., 1991, “9/9-9/1 Scale Method of AHP,”.2nd Int. Symposium on AHP, Pittsburgh, pp. 197-202.
[17] Salo, A. and Hamalainen, R., 1997, "On the Measurement of Preference in the Analytic Hierarchy Process," Journal of Multi-Criteria Decision Analysis, 6(6), pp. 309-319.

[18] Saaty, T. L., 1990, "How to make a decision: the analytic hierarchy process," European journal of operational research, 48(1),pp. 9-26.

[19] Bascetin, A., 2007, “A decision support system using analytical hierarchy process (AHP) for the optimal environmental reclamation of an open-pit mine," Environmental Geology, 52(4),pp. 663-672.

[20] Saaty, T.L., 1980, "The Analytic Hierarchy Process," McGraw-Hill International, New York, NY, U.S.A.

[21] Ramanathan, R., 2001, "A note on the use of the analytic hierarchy process for environmental impact assessment," Journal of environmental management, 63(1), pp. 27-35.

[22] Aminbakhsh, S., Gunduz, M. and Sonmez, R.,2013,"Safety risk assessment using analytic hierarchy process (AHP) during planning and budgeting of construction projects," Journal of safety research, 46,pp. 99-105.

[23] Kahraman, C., Cebeci,U. and Ulukan, Z.,2003, "Multi-criteria supplier selection using fuzzy AHP," Logistics information management, 16(6), pp. 382-394.

[24] Subramanian,N. and Ramakrishnan, R., 2012, "A review of applications of Analytic Hierarchy Process in operations management," International Journal of Production Economics, 138(2), pp. 215-241.

[25] Lai, V. S., Bo, K. W. and Waiman, C. , 2002, "Group decision making in a multiple criteria environment: A case using the AHP in software selection," European Journal of Operational Research,137(1), pp. 134144.

[26] Wei, C. Chen-Fu, C., and J. Mao-Jiun, W., 2005, "An AHP-based approach to ERP system selection,", International journal of production economics, 96(1), pp. 47-62.

[27] Melvin, A., 2012, "Decision-Making Using the Analytic Hierarchy Process (AHP) and JMP Scripting Language", JMP User Community.

[28] Lu, Y. and Ramamurthy, K., 2011, "Understanding the Link between Information Technology Capability and Organizational Agility: An Empirical Examination,”, MIS Quarterly, 35(4), pp. 931-954.

[29] Dove, R., 2005,'Agile enterprise cornerstones: knowledge, values, and response ability," Business agility and information technology diffusion, pp. 313-330.

[30] Salman,N. and Pinsonneault, A.,2012, "IT and firm agility: an electronic integration perspective,", Journal of the Association for Information Systems,13(3), pp. 150.

[31] Gallagher, K. P. and Worrell, J. L.,2008, "Organizing IT to promote agility," Information technology and management, 9(1), pp. 71-88.

[32] Roberts, N. and Grover, V.,2012, "Investigating firm's customer agility and firm performance: The importance of aligning sense and respond capabilities," Journal of Business Research, 65(5), pp. 579-585.

[33] Marhraoui, M. A. and El Manouar A., 2017 "IT-enabled organizational agility-Proposition of a new Framework," Journal of Theoretical and Applied Information Technology, 95(20), pp.5431-5442.

[34] Siraj, S., Mikhailov, L. and Keane, J. A.,2015, "PriEsT: an interactive decision support tool to estimate priorities from pairwise comparison judgments," International Transactions in Operational Research,22(2), pp. 217-235.

[35] Goepel, K. D., 2014, "BPMSG AHP Online System: Multi-Criteria Decision Making Using the Analytic Hierarchy Process,". 